\title{
Fucidin in patients on haemodialysis
}

\author{
J. A. E. HOBBY, LINDA BEELEY, AND J. L. WHITBY \\ From the Renal Unit, The Queen Elizabeth Hospital, Birmingham
}

SYNOPSIS Fucidin is useful against 'antibiotic-resistant staphylococci' which are a major problem in causing shunt site infections in patients on chronic intermittent haemodialysis for 3 end-stage renal failure. A new form of intravenous fucidin has been used in vivo in three patientsp on haemodialysis, and also in experiments in vitro in order to assess its dialysing properties $\vec{\vartheta}$ The experiments in vitro show that some fucidin does cross the dialyser membrane but, in the patients studied, adequate serum levels were maintained throughout a 10-hour haemodialysis. A single intravenous dose of Fucidin is, therefore, adequate for treating 'antibiotic resistant' staphylococcal infections in patients during haemodialysis.

Chronic intermittent haemodialysis is now an established form of treatment for end-stage renal failure and it is therefore of clinical importance to determine the dialysis properties of as many antibiotics as possible. In patients maintained by regular haemodialysis infections of the arteriovenous shunt site are a major problem. These infections are frequently due to 'antibioticresistant staphylococci', and Fucidin has been shown to be a useful antibiotic in the treatment of infections due to such organisms (Porter and Wilson, 1963).

In normal individuals Fucidin is excreted almost entirely by the liver, very little appearing in the urine (Godtfredsen, Roholt, and Tybring, 1962). Its excretion should therefore not be impaired in patients with chronic renal failure. In patients undergoing haemodialysis, however, antibiotic may be lost across the dialyser membrane and dosage may have to be adjusted accordingly. To determine whether a significant amount of Fucidin is lost during the course of dialysis we have investigated the fate of a single intravenous dose in three patients on chronic intermittent haemodialysis.

\footnotetext{
Rec:ived for publication 25 Novembər 1969.
}

\section{Patients and Methods}

The three patients had all been on twice-weekly dialysis for more than two months. They were virtually anuric and had normal liver function Dialysis was carried out for 10 hours using the Capon Heaton twin minicoil (Simpson, Blainey? Dawson-Edwards, Hilton, and Williams, 1967危 in conjunction with the Lucas haemodialysis machine (Simpson, Blainey, Dawson-Edwards $>$ Hilton, and Wilson, 1967).

A single dose of $500 \mathrm{mg}$ of Fucidin in $25 \overline{\mathrm{Q}}$ $\mathrm{ml}$ of saline was administered intravenously ovefr a period of two hours on two separate occasions (1) at the onset of a 10-hour dialysis and (2) ond a day between dialyses. Samples of blood were obtained 10 minutes after the end of the infusion and thereafter at three, six, nine, and 10 hour (at the end of dialysis). The serum was separatedes? frozen, and subsequently assayed for Fucidin.o For antibiotic assay $150 \mathrm{ml}$ of medium pree seeded with Staphylococcus aureus (NCT 6571) was poured in levelled 10 in. square glas plates. Holes were cut with a $6 \mathrm{~mm}$ cork boref and standards and samples added using a quast latin square random distribution. The metho gives satisfactory results down to levels of approxs 


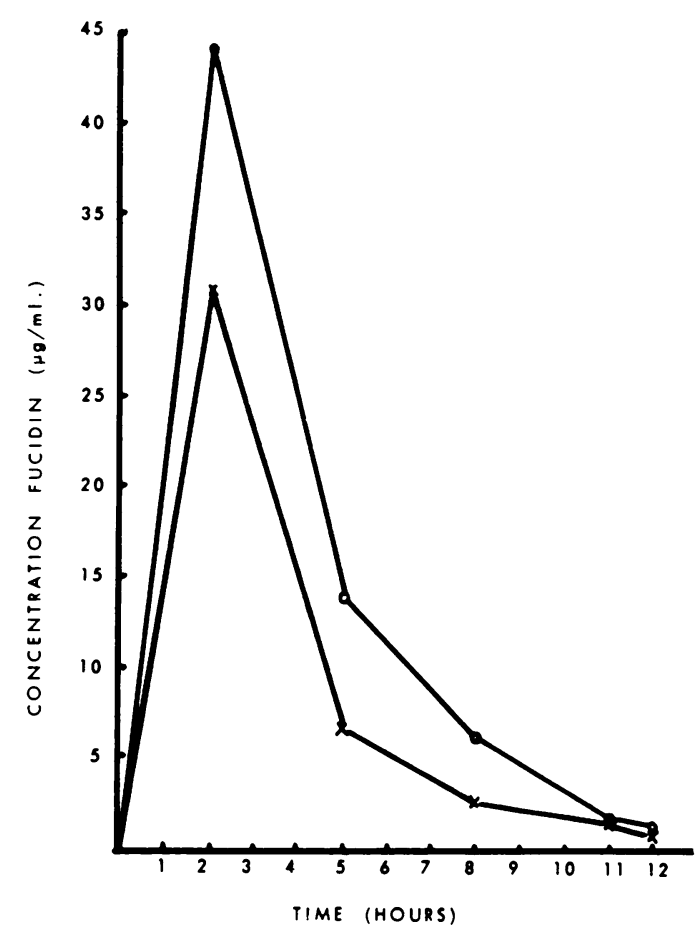

Fig. 1

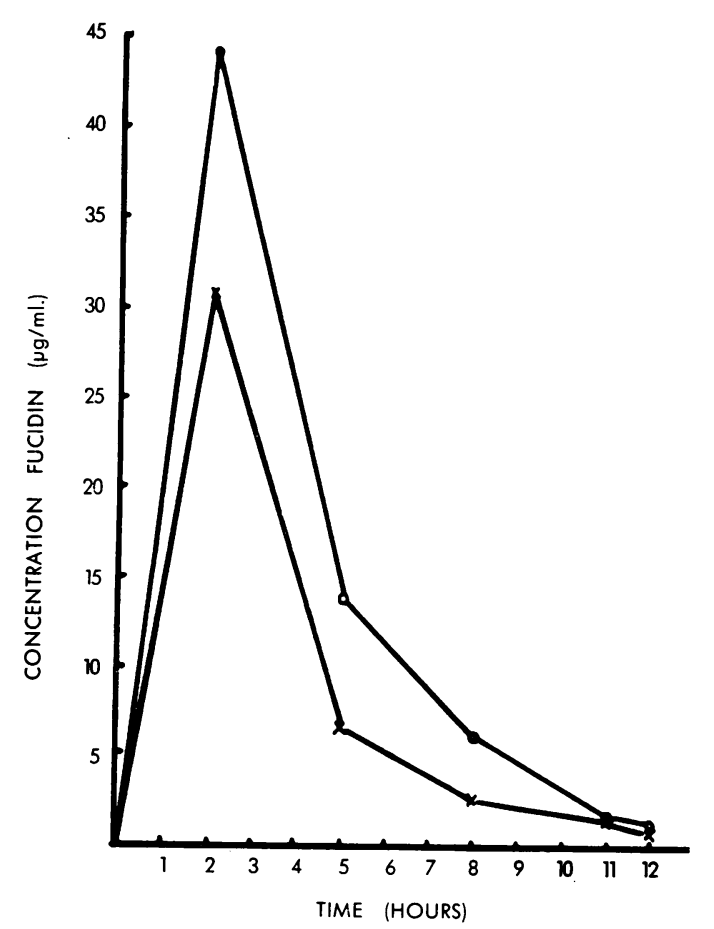

Fig. 3

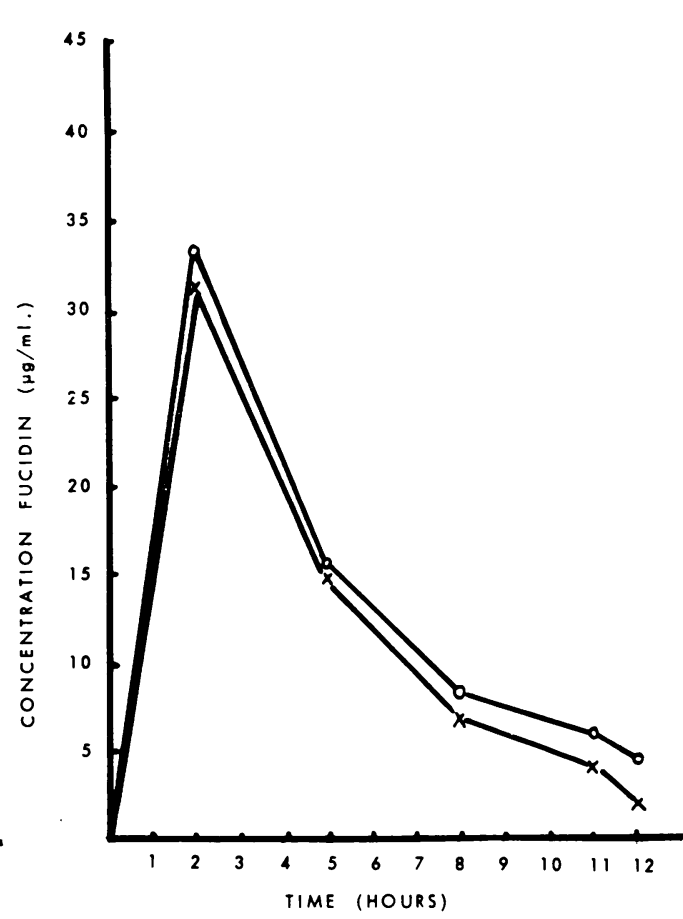

Fig. 2

Figs. 1, 2, and 3 The variation of serum level os $\overrightarrow{\vec{\rho}}$ Fucidin with time following a single intravenous dose in patient T.M. (Fig. 1), in patient P.S. (Fig. 2) and in patient M.W. (Fig. 3).

$O-O$-patient on haemodialysis, $X$ - $X$-repeat experi ment on a day between dialysis.

imately $1 \mu \mathrm{g} / \mathrm{ml}$ in serum and much lower levels? in buffer. Serum levels were plotted against times and the results are shown in Figures 1, 2, and 3.으.

As our results suggested that dialysis had now effect on the rate of fall of the serum Fucidin levels, an experiment was performed in vitro Two solutions, one containing 6,200 $\mu$ g Fucidinw in $10 \mathrm{ml}$ of distilled water, and the other con? taining $6,200 \mu \mathrm{g}$ Fucidin in $10 \mathrm{ml}$ of pooledo human serum, were dialysed against $100 \mathrm{ml}$ of dialysate for 18 hours. The level of antibiotic ${ }^{+}$ in the original solution was assayed in paralle[ with the level in the same solution after dialysis? and the level in the dialysate after dialysis. The? results are shown in the Table. It can be seer $\mathbb{D}$ that while equilibrium was obtained in the non protein-containing dialysis fluid, far less Fucidin dialysed from the protein-containing solution 0 Fucidin is known to be $\mathbf{9 7 . 2} \%$ protein bound in 


\begin{tabular}{|c|c|c|c|c|c|c|}
\hline & \multicolumn{4}{|c|}{$\begin{array}{l}\text { Antibiotic inside Dialysis } \\
\text { Tubing }\end{array}$} & \multicolumn{2}{|c|}{$\begin{array}{l}\text { Antibiotic in Dialysate } \\
\text { after } 18 \text { Hours }\end{array}$} \\
\hline & \multicolumn{2}{|c|}{ At Start } & \multicolumn{2}{|c|}{ After 18 Hours } & \multirow[b]{2}{*}{$\begin{array}{l}\text { Total } \\
(\mu g)\end{array}$} & \multirow[b]{2}{*}{$\begin{array}{l}\text { Concentration } \\
(\mu g / m l)\end{array}$} \\
\hline & $\begin{array}{l}\text { Total } \\
(\mu g)\end{array}$ & $\begin{array}{l}\text { Concentration } \\
(\mu \mathrm{g} / \mathrm{ml})\end{array}$ & $\begin{array}{l}\text { Total } \\
(\mu g)\end{array}$ & $\begin{array}{l}\text { Concentration } \\
(\mu \mathrm{g} / \mathrm{ml})\end{array}$ & & \\
\hline \multirow{2}{*}{$\begin{array}{l}\text { Fucidin in } \\
\text { human serum } \\
\text { Fucidin in } \\
\text { water }\end{array}$} & 6,200 & 620 & 5,600 & 560 & 540 & 5.4 \\
\hline & 6,200 & 620 & 640 & 64 & 5,500 & 45 \\
\hline
\end{tabular}

Table Comparative results in vivo and in vitro.

serum (Rolinson and Sutherland, 1965), and presumably protein binding is the reason for the low levels in the dialysate and also for the finding in vivo that dialysis does not alter the rate of fall of serum Fucidin levels.

\section{Comment}

Although the studies in vitro showed that some Fucidin does cross the dialyser membrane, dialysis had no effect on the rate of fall of serum Fucidin levels in our three patients. The rate of fall after a dose of $500 \mathrm{mg}$ intravenously is such that therapeutic levels are maintained for at least 10 hours (Barber and Waterworth, 1962; Godtfredsen et al, 1962) and no modification of the dosage schedule is required during dialysis.

Both oral and intravenous Fucidin are available for use, but in the treatment of shunt infections intravenous antibiotic therapy is preferable because of the need to produce therapeutic levels at the site of infection as quickly as possible to $\frac{\rho}{\bar{\sigma}}$ preserve the shunt and prevent septicaemic com= plications. In addition we have found the severe gastrointestinal side effects of oral Fucidin t $\bar{Q}$ be a limiting factor in its use, and these do not: occur using th: intravenous route. Venospasnef and subsequent thrombosis have been reporte following injection of Fucidin into a peripheras. vein (personal communication), and for this reason the manufacturers advise the abov $\&$ method of administration. However, this shoulक not be a problem when Fucidin is given into an arteriovenous shunt where the blood flows fast.

We should like to thank Dr J. D. Blainey and Mr P. Dawson-Edwards for allowing us to investigate their patients, and Leo Laboratories for supplying the intravenous Fucidin.

References

Barber, M., and Waterworth, P. M. (1962). Antibacterial activi in vitro of Fucidin. Lancet, 1, 931-932.

Godtfredsen, W., Roholt, K., and Tybring, L. (1962). Fucidin $\frac{3}{6}$ a new orally active antibiotic. Lancet, 1, 928-931.

Porter, I. A., and Wilson, J. S. P. (1963). Staphylococcal infections treated with fusidic acid in nurses. Lancet, 2, 658-659.

Rolinson, G. N., and Sutherland, R. (1965). The binding of antibiotics to serum proteins. Brit. J. Phurmacol., $2 \$ ?$ 638-650.

Simpson, K. M., Blainey, J. D., Dawson-Edwards, P., Hiltow D. D. and Williams, B. T. (1967). The twin minicot artificial kidney. Lancet, 1, 1244-1247.

Simpson, K. M., Blainey, J. D., Dawson-Edwards, P., Hilto D. D., and Williams, B. T. (1967). A new low cost sing patient proportionating and monitoring system for haemo dialysis. In Replacement of Renal Function: Proceedings of the 3rd Conference of the European Dialysis and Tran plant Association (Excerpta med. int. Congr. Ser., 13! pp. 319-321. Excerpta Medica Foundation, Amsterdam. 